\title{
Reinvigorating Exploration Nature: An of Ecopoetics in Pearl S. Buck's The Good Earth
}

Greenu Ans Thomas

Guest Lecturer

Department of English

St. Thomas College

Pala, Kottayam, Kerala, India

greenuans@gmail.com

\begin{abstract}
The Good Earth (1931) by the American author, Pearl S. Buck (1892-1973) is recognised for its predominant theme of the nourishing power of the land. Buck's novel situates this universal theme within the context of traditional Chinese culture. Wang Lung, a farmer, has an intimate relationship with the earth because he produces his harvest through his own labour. Buck suggests that Wang Lung's reverence for nature is responsible for his inner goodness, as well as for his increasing material success, and that the decadent, wasteful ways of the wealthy are due to their estrangement from the land. Buck also suggests throughout the book that while human success is transitory, the earth endures forever. These ideas about the earth give the novel its title.

The novel is recognised for its glorification of land and soil as the foundation of life. Throughout the novel, a connection to the land is associated with moral piety, good sense, respect for nature, and a strong work ethic, while alienation from the land is associated with decadence and corruption. This paper is an attempt to offer viable alternatives to reconstitute
\end{abstract}


ecocritical ideas in The Good Earth and to evaluate them in terms of their coherence and usefulness as responses to the worsening environmental crisis.

Keywords: Ecocriticism, Green Studies, Despotism, Dominion, Symbiosis, Anthropocentrism, Ecocentrism

"It is the end of the family - when they begin to sell the land... Out of the land we came and into it we must go - and if you hold your land you can live - no one can rob you of land" (Buck 385). This quotation can be considered as the very essence of the novel The Good Earth by the American author, Pearl S. Buck. The protagonist Wang Lung's speech at the end of the novel is a final plea to honour man's relationship with the land. These words of admonition clearly predict the impending downfall of the family and are particularly relevant in the present scenario of growing irreverence to land. The novel is recognised for its glorification of "the land" and "the soil" as the foundation of life, which is indeed suggested through its title.

The novel, which dramatises family life in a Chinese village before World War I, has been a steady favourite ever since. This tells the poignant tale of a Chinese farmer and his family in old agrarian China. The humble Wang Lung glories in the soil he works, nurturing the land as it nurtures him and his family. Nearby, the nobles of the House of Hwang consider themselves above the land and its workers; but they will soon meet their own downfall. Hard times come upon Wang Lung and his family when flood and drought force them to seek work in the city. The novel follows the life of Wang Lung, who gradually, through both hard work and unexpected fortune, acquires more land and money than he had ever dreamed of owning. Though Wang Lung gets temporarily caught up in the trappings of wealth, for instance, taking on a concubine named Lotus and dressing himself in lavish silk robes, he eventually grows to re-appreciate the simple life of a hard-working farmer. His 
sons, however, lack their father's work ethic and by the novel's conclusion it appears likely that the fruits of Wang Lung's toils will be squandered by the excesses of the next generation.

Buck keenly perceives the complicated relationship between the protagonist Wang Lung and the land during the different periods of his life. Wang Lung is attached to the land in terms of material and spirit. She also draws parallels between the natural cycle of growth, death, and regeneration and the rise and fall of human fortune and human life. When O-lan gives birth to her first two sons, for instance, she immediately returns to tending the fields, which connects the creation of human life to the bounty of the earth. Similarly, the droughts, floods, and famines that ruin the earth's harvest are metaphorically linked to death and downfall.

The Good Earth thematises the relationship between people and the land. Terms like farms, fields, land, earth, dust and soil pop up over and over again in the novel, as Wang Lung, O-lan and the other hard-working characters of the novel work in the land. Buck reinforces the theme by repeatedly demonstrating Wang Lung's attachment to his land. For instance, Wang Lung is illustrated as being concerned about his crops- "The farmer in Wang Lung was diverted for an instant and he stooped to study the budding heads" (Buck 19). Another example can be found where Wang Lung yearns for his land when he is stranded in the south to escape the famine. He cries out, "Shall I never see it again" (98). This statement shows Wang Lung's emotional attachment to his land. Buck paints the fortunes of Wang Lung's family as no different from the fortunes of any other family. Families, like the seasons, follow a cycle, and Buck suggests that Wang Lung's sons are likely to ruin themselves by abandoning the land.

The idea that all human life begins and ends in the unchanging earth is the bedrock of the novel, as well as the source of its title. The novel repeatedly insists that the land deserves respect and that those who do not accord it this respect will eventually fall on hard times. The 
famine that reduces Wang Lung to grinding poverty provides a glimpse of the hard life facing poor farmers in old China. The drought is also a reminder that the earth is the only constant force in the world. For all of his hard work, Wang Lung is subject to the whims of nature. The novel's large theme is that the fortunes of humanity are transitory compared to the earth's permanence.

The book of Genesis is often quoted as a scriptural license for human despotism upon nature: "And God said, let us make man in our image, after our likeness: and let them have dominion over the fish of the sea, and over the fowl of the air, and over the cattle, and over all the earth" (Gen. 1:26). The meaning of the word 'dominion' has been twisted and misinterpreted so as to justify man's supremacy over all living things, leading the way towards ecologically damaging attitudes. Contradicting the misread role of nature in the Bible, Jeanne Kay argues, "Nature is God's tool of reward and punishment, and its beneficence depends on human morality." (Garrard 109)

The Good Earth, has the theme of one's relationship to the earth. Farming in China, famine in China, the life of the family, love for the good brown earth, all these are here. But deeper than this, the whole story is universally human. The pathos and tragedy of man's life everywhere is felt to be closely akin to that which one follows with keen and instinctive interest from beginning to end of this book. This novel gives a picture of that section of common people, lowly and homely, through the experiences of the man, Wang Lung, who is the centre of the action.

One leaves it feeling better aware of the sorrows, joys and ambitions of the folk of vast China; but, too, with tolerant sympathy with the foibles, longings and loyalties of simple people everywhere. To accomplish this, it would seem, is the very kernel of literary art. The readers are taken through the struggle of the peasant farmer Wang Lung and his big-footed wife O-lan, whose lives are intertwined with the "good earth" from which they struggle to 
eke out a living. These sentiments are established from the very beginning of the novel. O-lan and Wang Lung work the land together harmoniously, both having a deep reverence for the land. In the course of time, endless natural calamities are visited upon them, but none are so destructive as the greed, lust, and idleness that are the by-products of their eventual wealth.

When Wang Lung hears that the Hwang family wishes to sell land, he is shocked. Because land is directly connected with life, he cannot imagine parting with it and is surprised to hear that the Hwangs would sell it. For him, land is the most precious of all wealth because nobody can take it away.

He said in his heart, "They cannot take the land from me. The labour of my body and the fruit of the fields I have put into that which cannot be taken away. If I had the silver, they would have taken it. If I had bought with the silver to store it, they would have taken it all. I have the land still, and it is mine.” (Buck 79)

Thus, when Wang Lung and his family go to the southern city during the famine, Wang Lung continually yearns for the land. Although life in the city is hard and agonising, the thought that his land is back home waiting for him brings him peace and comfort. When Wang Lung learns that his second son has stolen a piece of meat from a woman, he is in despair because his sons are growing up as thieves in the city. He tells himself that they must go back to the land because city life is corrupting and evil. "We must get back to the land" (119). There is a sense that the land is where innocence and honesty reside.

Wang Lung's father, like Wang Lung, also cherishes an unwavering faith in the land. When Wang Lung yearns for the land, wanting to return to it, the father understands him well. He tells Wang Lung that there were times in his life when he also had to leave the land. When Wang Lung reminds his father that he always returned, the old man simply replies that it was because there was the land. He too dreams of going back to his land: 
Well, they also would go back, if not this year, then next, said Wang to his own heart. As long as there was the land! And the thought of it lying there waiting for him, filled him with desire. He went back to the hut and he said roughly to his wife, "If I had anything to sell I would sell it and go back to the land..."(124)

Wang Lung is always devoted to his land. When other men talk about doing different things with money, Wang Lung talks of buying land from which to reap harvests. Others ridicule him for it, but he is resolute, not minding their scorn for him. When Wang Lung and his family finally do return to the land, he cannot part from it nor can he stop thinking about it. Wanting to be alone with his land, Wang Lung spends many days planning and thinking about what to plant.

Wang Lung is not the only character in the book who knows the value of the land. Even Cuckoo, the slave who sells him the Hwang land, tells him that the reason for the fall of the Hwang family was the family's heedlessness to the land. Wang Lung forgets the land for awhile when he is sick in love with Lotus. When Lotus comes to his house, he is plagued by various domestic problems, but when the waters in the fields recede and Wang Lung is able to work his land, he is immediately healed of his sickness. Thus, the earth is a healing agent for Wang Lung. O-lan also acknowledges and respects the earth. As she lies dying, O-lan tells Wang Lung that he must not sell the land in his futile attempts to cure her. She will die sometime, but the land will always be there, even after her death. It is forever constant.

Over the years, Wang Lung ages and changes, but one thing remains within him - his consideration and never failing love for the land. Although he leaves it for awhile after having built his fortune, he always returns to the land every spring. He always cherishes a strong love for the land. When he discovers that his sons do not value the land, reminds his eldest son of the importance of land: "It is the good land that has made you something better 
then a farmer's lad" (287). Later, in an effort to instil a passion for the land in his sons, Wang Lung says, "Well, even great families are from the land and rooted in the land... And roots, if they are to bear fruits, must be kept well in the soil of the land" (334).

Since time immemorial, the relationship between the natural world and the human world had been one that was grounded on mutual cooperation and harmonious co-existence. This symbiosis got disturbed in the course of time, as man grew self-centred and profitminded. Nature itself opened human eyes through the natural calamities unleashed, thus turning a darker face. As part of man's revelation of the unfathomable consequences of the resulting environmental imbalance, growing environmental concerns and eco-friendly action plans represent today's society. In such a scenario wherein ecocriticism has gained momentum as never before, to delve into the matters of man-nature bond as in Pearl S. Buck's The Good Earth is of great contemporary relevance. The work, which presents earth as the giver and sustainer of life, validates the "back to nature phenomena" which is in vogue now. Buck explores the ideal relationship between human and nature. The protagonist, Wang Lung's attachment to the land reveals the portrayal of a world based on ecological thoughts.

The novel begins on the day of Wang Lung's wedding. Wang Lung is a poor young peasant who lives in an earthen brick house with his father, who has arranged for him to marry a slave girl named O-lan from the great family of the House of Hwang. After Wang Lung brings his quiet but diligent new wife home, she works side by side with him in the fields until their first child is born. The following quotation describes Wang Lung's and Olan's connection to the land.

There was only this perfect sympathy of movement, of turning this earth of theirs over and over to the sun, this earth which formed their home and fed their bodies and made their gods . . . Some time, in some age, bodies of men and women had been buried there, houses had stood there, had fallen, and 
gone back into the earth. So would also their house, some time, return into the earth, their bodies also. Each had his turn at this earth. They worked on, moving together-together-producing the fruit of this earth (Buck 31).

Buck emphasises the cyclical nature of the earth. The repeated motions of "turning this earth of theirs over and over" parallels the image of people, homes, and fortunes rising up and falling back into the earth over and over again. This quotation is important as an early explanation of Wang Lung's ethical and spiritual connection to the land, and also as an emphasis on the recurring motif of the earth's permanence compared to the fleeting lives and fortunes of human beings.

As long as Wang Lung maintained an intimate relationship with the land, he continued to live his life according to sound moral principles. However, when made idle by the flood, he starts to contemplate his image and his social status. He looks at O-lan as a possession and finds her unworthy of a rich man. He realises he is rich in the first place only because of the help that O-lan has given him, both with her jewels and with her constant work and support. Even this realisation, however, does not stop him from becoming enamoured with possessions and another woman.

Wang Lung frees himself from his infatuation with Lotus. Thus, Buck emphasises the healing power of the earth in Wang Lung's life by connecting his downfall to a time when he is kept from working the land. She hints that Wang will be able to restore his good sense by giving himself back to the earth.

The fact that the first word of his sons' names at school means "one whose wealth comes from the land" suggests that Wang Lung should recall that he owes his good fortune to the land.

And from that time on the boys were no longer called Elder and Younger, but they were given school names by the old teacher, and this old man, after 
inquiring into the occupation of their father, erected two names for the sons; for the elder, Nung En, and for the second Nung Wen, and the first word of each name signified one whose wealth is from the earth. (136)

If the earth means merely one thing in the novel, it suggests constancy. Some years the harvest is plentiful, some years the harvest fails, but as long as a person owns a piece of the earth, comfort and nourishment will come again. Wang Lung's prosperity directly corresponds to the amount of land he owns, and his family's wealth follows from his understanding of and love of the fields. Moreover, O-lan, the character most responsible for his success, is thematically linked to the earth in terms of her brown colour, her plain determined personality, and her fertility. In addition, the boys of Wang Lung are called Nung En and Nung Wen at school; 'Nung' means 'one whose wealth is from the earth'.

This is again indicative of his own deep-rooted awareness that earth is his family's provider and his hope that his sons too follow his path, believing in the power of the earth.

By the novel's end, contrary to his wish, the connection between Wang Lung's family and the earth is almost totally severed. Wang Lung's sons have all chosen different paths, and though their comfort has been built from land-ownership and farming, they have little interest in continuing these pursuits. The novel ends with Wang Lung's sons speaking about selling the land, something that greatly distresses Wang Lung but that strikes the reader as inevitable.

The last scene of the book is a poignant one in which Wang Lung hysterically yells at his two sons when he overhears them talking about selling the land. He is appalled and distressed, unable to control his tears at the mention of selling the land. He scolds his sons, telling them that it will be the end of the family if they begin to sell the land. Land is where they have come from and where they must return. It is also the only constant thing that cannot be taken away. 
Wang emphasises again the earth's permanence and its place of central importance in human affairs through his final words to his sons, "If you sell the land, it is the end" (385). These words grimly and clearly predict the impending downfall of the family which Wang's hard work and piety have made rich. These words can be taken as a warning in the present situation in which human beings consider the earth as a mere commodity to amass more wealth. This forewarning must lead us through ways to honour the earth and to put an end to self-destruction through excessive exploitation of nature.

"I feel no need for any other faith than my faith in the kindness of human beings. I am so absorbed in the wonder of earth and the life upon it that I cannot think of heaven and angels.” (http://www.goodreads.com/quotes/178992). These words of Pearl S. Buck reflect the deep-rooted sentiments that she shares with earth and the life on earth. In her fiction, she attempts to shed light upon the sense of honour with which one must approach the earth and life.

The Earth is the source of all basic elements that keep us alive. But with each passing day, the earth is facing major survival threats from human beings. Human beings have forgotten that the earth is their only hope of existence and they must not pollute or over populate it. The growing pollution is causing excessive damage to the earth and disrupting the balance of nature. The occurrence of natural disasters is more frequent than earlier, causing death of thousands of humans, plants and animals. Due to pollution and habitat loss, already many species of birds and animals are extinct and others are on the verge of extinction.

Deforestation and soil pollution have caused the death of many species of plants and made maximum number of plants and crops endangered. Human activities are slowly destroying the earth day by day. The temperature of earth has gone up by four degrees in past years because of global warming, leading to the melting of ice caps in poles. The water level 
of the earth has also up by several feet in last few years. The environment is collapsing due to toxic fumes, chemical waste and excessive noise caused by industrial applications. Immediate steps must be taken, as soon as possible, to stop the destruction or this might be the end of the human race. So, it is our sole responsibility to save the earth.

The human estrangement from nature is a matter of serious concern in the modern context, wherein men have grown extremely technology dependent and profit-driven. Agriculture's lack of appeal to young people is a distressing thing as it prefigures the imminent danger which mankind will be plunged into. Land grabbing is a sign for man's notion of the earth as a mere commodity which helps him climb the ladder of success in economic terms.

It is high time for man to go back to nature, the cradle which nurtured him until he turned against it. The value of the earth is long forgotten by the people in their pursuit to grab more profits, especially the younger generation. They abandon their own lands which they inherited from their ancestors and advance towards material benefits through technological enhancement. Thus, man moved more and more away from their Mother Nature, ushering in his own destruction. Regardless of the danger signs provided by nature itself, if man continues to advance in his path of exploitation, nothing less than total annihilation will be the end result. There is a quote from Silent Spring which suggests this perilous situation: "But man is part of nature, and his war against nature is inevitably a war against himself." (Carson, 93)

The shift from anthropocentrism to ecocentrism strikes an optimistic note which anticipates a harmonious man-nature relationship in the near future. This change in the mindset is a news of great relief and is also reflected in the field of literary criticism through theories like Ecocriticism and Green Studies. The shift from anthropocentricism to ecocentricsm has offered new room for critical studies. 
In the novel, The Good Earth, Pearl S. Buck resorts to symbols and depictions of Earth as a nurturer which have been long present in human societies. The Earth is the only world known so far to harbour life. There is nowhere else, at least in the near future, to which our species could migrate

The Good Earth may be read as a traditional rag-to-riches story, but the novel complicates this narrative by drawing the readers' attention to the cyclical nature of life. In an almost pastoral style, the novel describes the cycle of birth, marriage and death in a Chinese peasant family. It unravels the intricate relationship between the working of seasonal changes in nature and the different stages in human life. At the most fundamental level, agriculture follows a cyclical pattern. After harvest, the fields lie fallow before they are planted again, and after seven years of good crops, disaster usually strikes in the form of the flood and drought, as depicted in the novel. It can be noted that the characters' lives also enact this ebb and flow. The Great House of Hwang declines while the fortunes of Wang Lung and his family rise. But as the Wang family enjoys more prosperity, it is also clear that they are destined to repeat the Hwangs' mistakes. Wang Lung becomes distracted by women. His sons do not inherit his appreciation of the land, and they become increasingly estranged from the rich earth that gave rise to their wealth.

When Wang Lung asserts, "Land is one's flesh and blood" (53), Buck points to the mindset that human beings must possess in order to sustain their lives on the earth in complete harmony with nature. His reverence towards the earth proceeds further, that he boldly proclaims even in the hardest of times, "I shall never sell the land! Bit by bit, I will dig up the fields and feed the earth itself to the children and when they die I will bury them in the land, and I and my wife and my old father, even he, we will die on the land that has given us birth!" (91). Likewise, by the end of the novel, Wang Lung returns to the house where his father passed his days in the beginning of the novel. It is clear to him that he came from land 
and that he will return to it. To preserve and cherish the only home that we have ever known is far more than a matter of responsibility; rather, it is a way of expressing our gratefulness towards the eternal provider.

To sum up, the novel The Good Earth opens up the minds of the readers and leads through a journey in order to redeem the dwindled honour of the earth. Through the absorbing story of Wang Lung's life on the farm, his trip to the city when starvation threatens, and of his life until it is time for him to be claimed by the good earth, Buck succeeds in exploring the intricate connection between the man and nature.

We desperately need to save the Earth which is the only source of life and we must save it at any cost. Without earth there will be no existence of human race or any other species as no other planet till date can sustain life like earth does. Earth is our only home and we must be the harbinger of change. Hopefully, the present day witnesses certain changes that hints that man has regained his lost consciousness and he is seen coming back to nature. The increasing environmental concerns and ecological activities are a testimony to man's retrieved reverence towards the earth. This is a good sign that man has at least started distancing himself from the self-destructive activities which he had been indulging in. The natural calamities and other terrible outcomes have served as an eye-opener, at least to some sections of people. Quoting the famous words of Mahatma Gandhi, "There is enough on Earth for everybody's need, but not enough for everybody's greed." (http://www.goodreads.com/quotes/427443) 


\section{Works Cited}

Buck, Pearl S. The Good Earth. Washington Square Press, 2012.

Coupe, Laurence. The Green Studies Reader: From Romanticism to Ecocriticism. Routledge, 2000.

Garrard, Greg. Ecocriticism. Routledge, 2007.

Glotfelty, Cheryll and Fromm, Harold. eds. The Ecocriticism Reader. Georgia UP, 1996.

Rueckert, William. "Literature and Ecology: An Experiment in Ecocriticism." Essays in Ecocriticism. Norton Publishers. 1978. 